\title{
Geological Society of Africa
}

\section{http://www.elsevier.com/locate/gsa}

\section{History and objectives}

The ambitious and forward-looking decision to establish a panAfrican geological society was taken during the course of a conference on African geology held in Ibadan, Nigeria in 1970. A Steering Committee was convened at that meeting under the Chairmanship of Professor Russell Black of the Department of Geology, Haile Selassie University, Addis Ababa, and the provisional constitution drafted by his Committee was approved at a second conference on African geology in Addis Ababa in 1973. Thus was the Geological Society of Africa $(G S A f)$ born. Its first President was Professor M O Owawoye (Nigeria) and Dr S M El Rabba (Sudan) became its first Secretary General.

The main objectives of the society were:

- to promote the understanding of earth science in the African continent;

- to promote the training and development of African earth scientists, thereby assisting the newly independent African states to establish the manpower needed to enable the continent's wealth of resources to be developed for African benefit; and

- to provide a forum for discussion and dissemination of information and to promote cooperation between scientists and associations engaged in African geology, across national boundaries.

The early objectives remain valid today, although with changes of emphasis. The Society presently focuses particularly on international collaboration, the importance of earth science education and training, including the development of the role of African women earth scientists, and the responsible development of mineral and energy resources. In respect of the last of these, it seeks to promote the application of earth science to address resource-related environmental issues, including geohazards and water resources. It supports the establishment of national geological societies throughout the continent and, as best possible within its resources, meetings and workshops at international, regional and national levels. Internationally, the Society encourages its members to take a lead in developing collaborative projects under the UNESCO-IUGS International Geoscience Programme (IGCP). This initiative is now bearing fruit.

\section{Organisation and structure}

The Society is run by a Council serving a 3-year term of office, elected at the General Assemblies that are timed to coincide with the Society's major conferences. The key officers of the present Council comprise the Society President (Dr Felix Toteu, Cameroon), its Secretary General (Professor Nasser Ennih, Morocco), its Assistant Secretary General and Membership Secretary (Dr Read Mapeo, Botswana) and its Treasurer (Dr John Bennett, UK). These officers form a small executive group and are supported by five regional Vice-Presidents (representing GSAf in Northern, East, Central, Southern and West Africa) and Councillors from the same regions. Together, these officers represent the membership in all the main non-African language groups (Arabic, English, French, Portuguese) of the continent. The post of Editor/Information Officer (Dr Mengist Teklay, Eritrea) completes the make-up of the Council.

\section{Membership and external support}

The Society's members are drawn from over 30 countries in Africa as well as from outside the continent, a total (not all paid-up!) that exceeds 500 worldwide. New members, individual and institutional, are always welcome. Historically, the membership has been drawn largely from earth scientists attached to African and other universities. It seeks to redress this 'academic imbalance' by attracting more members from industry and from government agencies such as geological survey organisations, mines departments, water departments and environmental agencies and NGOs. It is particularly keen to encourage an increase in its institutional membership. Details of the membership categories, annual fees and methods of payment are given on the GSAf homepage.

Membership fees are purposely kept low, reflecting the ability of African members to pay, but this does constrain GSAf's activities and its ability to support events. The viability of the Society depends heavily, therefore, on support received from external donors. Key in this context is the assistance it receives from the International Union of Geological Sciences (IUGS). GSAf is an active Affiliate of the international body and the grant aid received from IUGS over the past several years has been the Society's main source of income. In addition, the Society has benefited from support from other interna-

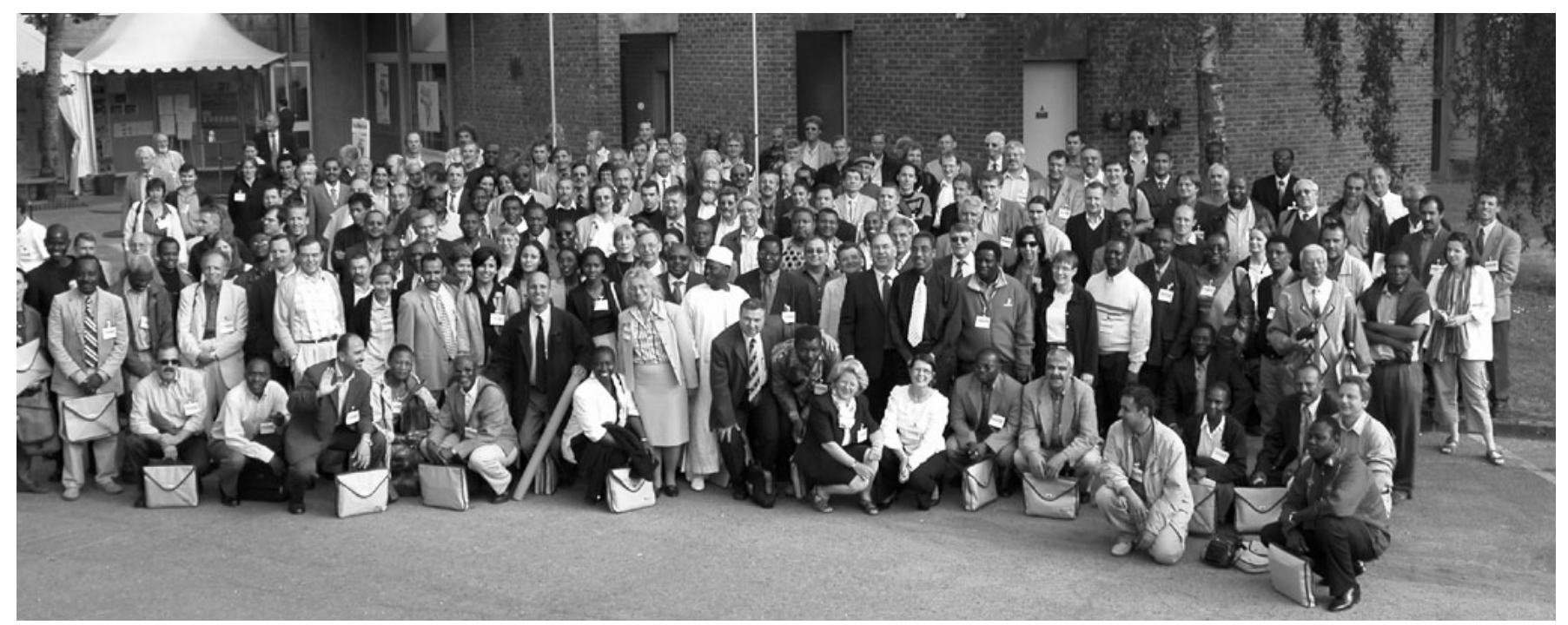

The 20th Colloquium of the Geological Society of Africa, held in June 2004 at Orleans, France. 
tional development agencies and industry, particularly to assist the implementation of its flagship events. The Society has also benefited indirectly from support by UNESCO to enable many African earth scientists to attend its meetings.

\section{Publications and information}

The Society produces a periodic newsletter, Africa Geonews, and maintains a website at www.elsevier.com/locate/gsa. The Editor/Information Officer is always pleased to receive members' news and information regarding meetings and workshops taking place throughout the continent and of similar events promoting African earth science development elsewhere in the world. GSAf does not publish its own journal. This is beyond its limited resources, financial and human. Instead, it encourages its members to publish the results of their work in the Journal of African Earth Sciences (JAES, Elsevier), Africa Geoscience Review (Rockview International, Paris), and Episodes (IUGS).

The Society has recently re-initiated its Fellowship scheme to recognise members who have given valuable service to the Society and to African earth science. It has also recently established its Robert Shackleton Award to recognise significant contributions to African Precambrian research by members. Information about both of these awards is available on the homepage and nominations are welcomed.

\section{Major activities}

The Society organises two major international meetings: its own International Conference and the biennial Colloquium of African Geology. The former is held on a rotating basis and following successful meetings in Nairobi (1995), Cape Town (1999) and Yaoundé (2001), the next meeting is scheduled to take place in Cairo in December 2005. The conferences have attracted upwards of one hundred and fifty participants drawn widely from the African countries and elsewhere, such is the interest and appeal that Africa continues to hold for earth scientists, and such is the need that still exists for information and knowledge to help advance development in a continent that, alas, continues to face major problems.

The Colloquium of African Geology has its origins in the 1950s and 1960s. Initially its precursor provided a forum to enable (predominantly British) researchers to meet periodically to exchange ideas and present results of ongoing work in Africa. This gradually evolved into the present Colloquium, although it remained a predominantly European-based and led event until the end of the 1980s. During the meeting in Berlin (1987) and with the increase in numbers and the growing emergence of African earth scientists, pressure understandably mounted to hold the Colloquium in Africa. At this stage GSAf was encouraged to take over the organisation of the event and a pattern of holding meetings alternately in Africa and Europe was adopted. The first Colloquium in Africa was held in Swaziland (1993), since then further colloquia in the continent have been held in Zimbabwe (1997) and Morocco (2002). The next Colloquium is to be held in Mozambique in 2006.

The Society supports regional and local events and encourages grassroots activities by its members. Examples of meetings supported and/or co-organised by the Society include those in Angola (2000), Guinea (2000), Uganda (2001), Nigeria (2003), Egypt (2003, 2004), Ethiopia (2004) and the Association of African Women Geoscientists (meetings in South Africa (2002) and Uganda (2004)). For all these events the Society has provided grants principally to assist the participation of African scientists by providing travel and/or subsistence support. Similar support has been granted to individuals for exchange and training purposes. GSA $f$ has also encouraged the establishment of national geological societies and associations in Cameroon, Eritrea, Guinea, Mozambique, Senegal and Uganda in recent years, providing seed-funding when appropriate and timely to help meet the costs of inaugural meetings.

\section{The future?}

Like all societies, the Geological Society of Africa has experienced its ups and downs during its 31-year history and will no doubt continue to do so. It has achieved much against considerable odds, as the activities outlined above will, it is hoped, indicate. By its very nature, however, the Society remains a somewhat nebulous, farflung organisation. It lacks a central secretariat and contact with its wider membership is tenuous, even with the improving access to the Internet across the continent. Funding remains uncertain and GSAf, in common with national societies, needs to increase its lobbying of governments and regional agencies, to build awareness of the role earth science can play in the continent's development and of the ever-improving skill base that now exists within the African earth science community at large, and within its own membership. It also needs to develop its links with sister organisations within the continent and beyond.

Notwithstanding its limitations, the Society has raised its profile significantly in the past decade and is managing to spread its resources and its presence widely, if thinly, across national boundaries. Arguably, it remains the only African geological society that is primarily pan-African and truly international in its outlook and aims. The wide-ranging nationalities of the Council and the general membership and its varied programme of activities in different locations around the continent and beyond reflect this. However uncertain and troubled the future may appear, the Society remains well-positioned in principle to build on its present base. Societies such as GSAf, though, are 'people businesses' and the will needs to be found to carry the Society forward. This is the challenge the Geological Society of Africa must rise to in the years ahead.

(This profile was prepared by J D Bennett, GSAf Treasurer. Opinions expressed represent his personal views. The text has, however, benefited from comments by colleagues in the Society and also draws on the following published material:

Bennett, J D, 2000, Out of Africa: Geoscientist, v.10, no.12, p.13. Muhongo,S, 1996, The Geological Society of Africa - role and objectives for the 21st century: Episodes, v.19, no.3, p.66-70.])

\section{Dr. John D. Bennett}

Honorary Treasurer GSAf

Estuary View

The Strand, Lymnpstone

Exmouth EX8 5EY

$U K$

E-mail:jdb@jdbennett17.freeserve.co.uk

Prof. Nasser Ennih

Secretary General

Clouaib Doukkai University

BP 20El Jadida 24000

MOROCCO

Fax: 21223342187

E-mail:ennih@ucd.ac.ma

Dr. S. Felix Toteu

GSAf President

Center of Geological and Mining Research

BP 333, Garoua

CAMEROON

Fax: 237271335

E-mail: sftoteu@yahoo.fr 
